DR. DIEGO ALEJANDRO SAMPIETRO (Orcid ID : 0000-0003-2956-7484)

Article type : Original Article

\title{
Antifungal activity of Euphorbia species against moulds responsible of cereal ear rots
}

Cristina M. Jiménez ${ }^{1, \dagger}$, Hebe L. Alvarez ${ }^{2, \dagger}$, María S. Ballari³ ${ }^{3}$ Guillermo R. Labadié3 ${ }^{3}$ César Atilio N. Catalán ${ }^{1}$, Ricardo E. Toso², Diego A. Sampietro ${ }^{1, \dagger}+*$

${ }^{1}$ LABIFITO, Facultad de Bioquímica, Química y Farmacia. Universidad Nacional de Tucumán, Ayacucho 471 (4000). San Miguel de Tucumán, Argentina.

${ }^{2}$ Centro de Investigación y Desarrollo de Fármacos (CIDEF), Facultad de Ciencias Veterinarias, UNLPam. Calle 116 y 5. General Pico, La Pampa (6360), Argentina

3 Instituto de Química de Rosario, UNR, CONICET, Suipacha 531, S2002LRK, Rosario, Argentina.

†These authors are joint first authors

Running title: Plant antifungals against moulds

* Corresponding Author.

Ayacucho 471 (4000)

San Miguel de Tucumán - Argentina

Tel: +543814247752 Int 7220

E-mail: dasampietro@hotmail.com

This article has been accepted for publication and undergone full peer review but has not been through the copyediting, typesetting, pagination and proofreading process, which may lead to differences between this version and the Version of Record. Please cite this article as doi: $\underline{10.1111 / J A M .14860}$

This article is protected by copyright. All rights reserved 


\section{ABSTRACT}

Aims

This work aimed to identify secondary metabolites from aerial parts of Euphorbia species functional for control of toxigenic Fusarium species responsible of cereal grain rots.

Methods and Results

Aerial parts of Euphorbia serpens, E. schickendantzii and E. collina were sequentially extracted with hexane, ethyl acetate and methanol. The extracts were tested against strains of $F$. verticillioides and $F$. graminearum by microdilution tests. The hexane extract of E. collina provided the lowest $\mathrm{IC}_{50} \mathrm{~s}$ on both fungal species.Further fractionation showed that cycloartenol (CA) and 24-methylenecycloartanol are associated to the moderate inhibitory effect of the hexane extract on fungal growth.Sublethal concentrations of CA and 24MCA blocked deoxynivalenol (DON) and fumonisins production.CA and 24MCA co-applied with potassium sorbate, a food preservative used for Fusarium control, synergized the growth inhibition of fungi. The mixtures reduced mycotoxins accumulation when applied at sublethal concentrations.

Conclusions

$\mathrm{CA}$ and 24MCA inhibited both fungal growth and mycotoxins production. This fact is an advantage respect to potassium sorbate which increased the mycotoxins accumulation at sublethal concentrations.

Significance and Impact of the Study

CA and 24MCA synergized potassium sorbate and their mixtures offer a lower mycotoxigenic risk than potassium sorbate for control of the Fusarium species.

Keywords: Agriculture, biotechnology, fungi, food safety, preservatives.

\section{INTRODUCTION}

Fusarium verticillioides and $F$. graminearum are important etiological agents of cereal ear rots (Belizán et al., 2019). They contaminate the grains with mycotoxins which have adverse health effects on humans and animals. Fumonisins and deoxynivalenol (DON) are among the most common mycotoxins found in grains. F. verticillioides is the main species associated with fumonisin production. Chronic consumption of fumonisins can lead to liver and kidney dysfunctions (Kamle et al., 2019). Fumonisins deplete sphingolipid biosynthesis which is believed 
responsible of esophageal cancer in humans (Myburg et al., 2002). They disrupt the cardiovascular system leading to leukaencephalamalacia in equines and pulmonary edema in pigs (Kamle et al., 2019). In the case of DON, it is often produced by F. graminearum. DON intake inhibits protein synthesis and induces strong oxidative stress (Pestka, 2008). It has been associated with diarrhea, emesis, anorexia, feed refusal and growth retardation observed in farm animals (Belizán et al., 2019). Prevention of Fusarium growth and mycotoxin contamination are mainly based on the application of azole fungicides at cereal flowering and food preservatives such as potassium sorbate during grain storage. Nevetheless, the uncontrolled use of fungicides has favoured the appearance of resistance in both $F$. verticillioides and F. graminearum (Kumle et al., 2019). It is noteworthy that azoles used in medicine and agriculture have a very similar structure. This fact does raise the possibility of the appearance of clinical Fusarium isolates less susceptible to azoles (Brauer et al., 2019). Additionally, current food preservatives can modify grain organoleptic properties at doses that completely suppress mold growth and sometimes trigger the accumulation of mycotoxins at subinhibitory concentrations (Jiménez et al., 2014). Hence, chemical control of Fusarium species requires the incorporation in the market of new antifungals or additives of existing antifungals. Euphorbia species might provide these compounds. In La Pampa province (Argentina), several Euphorbia species are widely used in folk medicine for wound healing and as antiseptic (Barboza et al., 2009). However, they have been scarcely investigated for their antimicrobial compounds. In this work, we tested the antifungal activity of extracts from $E$. serpens, E. schickendatzii and E. collina against Fusarium strains and identified the bioactive compounds involved.

\section{RESULTS}

\section{Impact of the plant extracts on fungal growth}

The methanol, ethyl acetate and hexane extracts obtained from aerial parts of the Euphorbia species were tested against the Fusarium strains. The extracts of E. serpens and E. schikendantzii and the methanolic extract of E. collina did not exhibit antifungal activity in the microdilution tests. For this reason, Table 1 displays $\mathrm{IC}_{50} \mathrm{~S}$ only for the hexane and ethyl acetate extracts of $E$. collina. Both fungal species showed the lowest values when exposed to the hexane extract. They were equally sensitive to the ethyl acetate extract, with $\mathrm{IC}_{50} \mathrm{~s}$ that were similar to the values recorded for potassium sorbate and two to four fold higher than the $\mathrm{IC}_{50} \mathrm{~s}$ of the hexane extract. 
The hexane and ethyl acetate extracts of E. collina showed an antifungal effect several orders of magnitude weaker than that of tebuconazole.

\section{Isolation of antifungals from the methanolic extract of $E$. collina}

The hexane extract of E. collina was subjected to a bioassay guided isolation. Pools and fractions recovered during the separation steps were tested by microdilution. However, antifungal activity only was found for the pool G10 recovered from the column chromatography of the hexane extract and the fractions F1 and F2 collected after HPLC of pool G10 (Table 2). Strains of $F$. verticillioides were similarly inhibited by pool G10, F1 and F2. The same was observed for strains of F. graminearum. GC-MS analysis displayed in Figure 1 and Table 3 indicated that G10 was a mixture of $51 \%$ cycloartenol (CA) and 49\% 24-methylenecycloartanol (24MCA). These compounds were recovered from HPLC of G10 in fractions F1 and F2. GC-MS analysis of F1 and F2 indicated that they comprised $98 \%$ of CA and $97 \%$ of $24 \mathrm{MCA}$, respectively.

\section{Joint action between the isolated antifungals and potassium sorbate}

CA and 24MCA synergized the growth suppression exerted by potassium sorbate (PS) on the Fusarium strains. This is indicated by the FICI values below 0.5 obtained for these pentacyclic triterpenes when combined with PS (Table 4). The combinations corresponding to the FICI values were $\mathrm{F} 1+\mathrm{PS}(375+188 \mu \mathrm{g} / \mathrm{ml})$ and $\mathrm{F} 2+\mathrm{PS}(94+188 \mu \mathrm{g} / \mathrm{ml})$ on $F$. graminearum, and $\mathrm{F} 1+\mathrm{PS}$ $(188+94 \mu \mathrm{g} / \mathrm{ml})$ and $\mathrm{F} 2+\mathrm{PS}(94+188 \mu \mathrm{g} / \mathrm{ml})$ on $F$. verticillioides. The partial concentrations at which PS participates in these blends mean a lowering of 1/8x MIC to 1/16x MIC when compared to the effect of PS alone.

\section{Antimycotoxigenic activity}

Sublethal concentrations of CA, 24MCA and their blends with PS were tested against the strains of both Fusarium species to know whether these compounds affect mycotoxin production (Table 5). F1 and F2 completely blocked the DON biosynthesis at concentrations higher than $94 \mu \mathrm{g} / \mathrm{ml}$ and at $188 \mu \mathrm{g} / \mathrm{ml}$ the biosynthesis of fumonisins. The mixtures strongly reduced the accumulation of mycotoxins although complete suppresion was not observed in the range of sublethal concentrations tested. The lowest DON and fumonisins accumulations recorded for F1+PS $(2: 1$, $\mathrm{w} / \mathrm{w})$ were at concentrations greater than $47+23 \mu \mathrm{g} / \mathrm{ml}$ and $94+47 \mu \mathrm{g} / \mathrm{ml}$, respectively. The mycotoxin contents registered at these concentrations indicate an average fall of $50 \%$ DON and 
$80 \%$ fumonisins respect to controls. F2+PS $(1: 2, \mathrm{w} / \mathrm{w})$ showed the smallest contents of DON at concentrations equal and higher than $23+47 \mu \mathrm{g} / \mathrm{ml}$, while the lowest levels of fumonisins were achieved at $47+94 \mu \mathrm{g} / \mathrm{ml}$. Compared to the controls, they showed average reductions in mycotoxin accumulations of $70 \%$ and $85 \%$, respectively.

\section{DISCUSSION}

The highest antifungal activity was observed for the hexane extract of E. collina while the remaining extracts were inactive or exhibited less inhibition on strains of both $F$. verticillioides and $F$. graminearum. Previous reports indicated antimicrobial and antihelmintic activities for extracts of some of the Euphorbia species investigated in this work. The methanolic extract of aerial parts of E. serpens, which was inactive on the Fusarium species at the concentrations and doses investigated here, suppressed the growth of Streptococcus lutea, S. aureus and E. coli at a dose of $10 \mathrm{mg}$ in disc diffusion tests and Vibrio cholerae at concentrations comprissed between 3.9 and $12.3 \mathrm{mg} / \mathrm{ml}$ in macrodilution assays (Bakhuni et al., 1974; Payne et al., 2015). Methanolic extracts of E. schickendantzii and E. collina were previously tested for antihelmintic activity which was moderate on Ancylostoma caninum at concentrations equal and higher than $7.5 \mathrm{mg} / \mathrm{ml}$ (Alvarez et al., 2018). The methanolic extract of E. schickendantzii also moderately inhibit the motility of Haemonchus spp at concentrations of 1 to $4 \mathrm{mg} / \mathrm{ml}$ (Lamberti et al., 2009). As far as we know, the current work reports for the first time antifungal activity associated to $E$. schickendantzii and E. collina. The search for the antifungal agents responsible of the antifungal activity of the hexane extract of E. collina led to the isolation and identification of GA and 24MGA. These pentacyclic triterpenoids are intermediates in plant biosynthesis of phytosterols and were reported in high contents into the aerial parts of several Euphorbia species (De Pascual et al., 1987; Zare et al., 2015;). They are naturally present in several plant foods and edible plant oils. CA and 24MCA possess pharmaceutical properties including the anti-inflammatory and antioxidant activities (Abidi, 2001; Zhang et al., 2017). Their effect on Fusarium species is reported for the first time in this work where they had a moderate to weak antifungal activity (MIC between 250 and $1000 \mu \mathrm{g} / \mathrm{ml}$ ). CA was reported with moderate to weak activity against clinical isolates of Candida albicans, Trichophyton mentagrophytes and Aspergillus niger (Ragasa et al., 2004), and inactive on the bacteria Streptococcus aureus and Bacillus subtilis, while 24MCA showed strong antiplasmodial activity on Plasmodium falciparum (Bickii et al., 2007).

This article is protected by copyright. All rights reserved 
The synergistic effect observed for CA and 24MCA might be used as a new strategy to reduce levels of PS needed for grain preservation. The best pairs of concentrations of CA+PS and 24MCA+PS offers the possibility to obtain a complete suppresion of fungal growth with PS concentrations of 188 and $375 \mu \mathrm{g} / \mathrm{ml}$, respectively. Depending of the food matrix considered, PS can be incorporated to foods in a range of concentrations comprissed between 3000 and $300 \mu \mathrm{g} / \mathrm{ml}$ (EFSA, 2015). Hence, a significant reduction of PS can be achieved with its co-application together with the pentacyclic triterpenes. The reasons of the synergistic action were not elucidated in this work. The antifungal activity of PS lies in its incorporation into the fungal cells as sorbic acid which is intracellularly accumulated and finally produces a disruption in the $\mathrm{pH}$ homeostasis (Plumridge et al., 2004). Sorbic acid also is able to directly act on several cellular targets including enzymes of the carbohydrate metabolism, the antioxidant system, and the citrate cycle (Sofos and Busta, 1981). CA and 24MCA might primarily act on fungal membranes as other pentacyclic triterpenes and likely interact with membrane constituents leading to an increase in membrane permeability which favour the entrance of extracellular sustances and the leakage of cell solutes (Haraguchi et al., 1999). It can be hypothezised that the pentacyclic triterpenes increased sorbic acid uptake which readily enhanced its inhibitory effect on fungal physiology. This point requires further research. In the case of tebuconazole, its mixtures with CA and 24MCA showed an additive/indifferent interaction. Altogether, the joint action tests indicate that CA and 24MCA had a mode of action different from that of the commercial antifungals tested and might be used in mixtures with sorbic acid-based food preservatives.

Both CA and 24MCA blocked the biosynthesis of the mycotoxins produced by the Fusarium strains. The antimycotoxigenic effect of pentacyclic triterpenes against DON and fumonisins producing fungi has been scarcely explored. Only lupeol was reported and had a strong blocking effect on DON and fumonisins accumulation (Sakuda et al., 2016). CA and 24MCA might affect mycotoxin biosynthesis due to their high lipophilicities and antioxidant capacities. Lipophilicity aids the entrance of the secondary compound into the fungal cells while the antioxidant power is believed to relieve the oxidative stress needed for mycotoxins biosynthesis (Castro et al., 2020). However, accumulation of DON and fumonisins depends not only of the intrinsic molecular properties of a secondary metabolite but also of other factors provided for fungal growth such as nutrient availability, temperature and water activity (Belizan et al., 2019). For this reason, additional studies are needed for a better understanding of how CA and 24MCA impact DON and

This article is protected by copyright. All rights reserved 
fumonisins accumulation under several environmental conditions faced by the Fusarium species during storage of cereal grains.

This work reports for the first time the antifungal activity of CA and 24MCA. Although they showed a moderate to weak inhibitory effect on growth of Fusarium strains, they had a significant antimycotoxigenic effect. Their synergistic interactions with PS raise a promisory use of CA and 24MCA in food preservation against $F$. verticillioides and $F$. graminearum responsible of cereal ear rots.

\section{AUTHOR'S CONTRIBUTION}

DAS, CANC, RET designed the study. HLA performed and supervised the plant collections, and extracted the plant materials. CMJ, HLA, DAS performed antifungal and antimycotoxigenic assays. MSB, GRL, CANC, DAS, HLA did separation and identification of molecules. DAS, HLA and CMJ analysed the data. DAS drafted and reviewed the manuscript. All authors read and approved the final manuscript.

\section{MATERIALS AND METHODS}

\section{Plant materials}

Aerial parts (leaves and stems) of Euphorbia serpens $(5 \mathrm{~kg})$, E. schickendantzii $(6 \mathrm{~kg})$ and E. collina (6 kg) were collected during january and february 2014 in La Pampa province (Argentina). The plant species were sampled in Trenel $\left(35^{\circ} 41^{\prime} 16^{\prime \prime} \mathrm{S}, 64^{\circ} 07^{\prime} 58^{\prime \prime} \mathrm{W}\right)$, Parque provincial Luro $\left(36^{\circ} 90^{\prime} 03^{\prime \prime} \mathrm{S}, 64^{\circ} 28^{\prime} 82^{\prime \prime} \mathrm{W}\right)$ and Colonia Emilio Mitre (36 $\left.26^{\prime} 27^{\prime \prime} \mathrm{S}, 66^{\circ} 27^{\prime} 89^{\prime \prime} \mathrm{W}\right)$. The plant materials were identified by biologist Hebe Lina Alvarez and the voucher specimens SRFA158 (E. serpens), SRFA161 (E. schickendantzii) and SRFA164 (E. collina) were deposited at the Herbarium of the Faculty of Agronomy (National University of La Pampa, Argentina).

\section{Microorganisms}

Strains of F. graminearum (NRRL 28063 and LABI11) and F. verticillioides (NRRL 25457 and LABI7) were provided by the LABIFITO culture collection (National University of Tucumán, Argentina). The strains were maintained in SNA medium (Spezieller Nahrstoffarmer agar: 0.1\% $\mathrm{K}_{2} \mathrm{HPO}_{4}, 0.1 \% \mathrm{NaNO}_{3}, 0.05 \% \mathrm{MgSO}_{4} .7 \mathrm{H}_{2} \mathrm{O}, 0.05 \% \mathrm{KCl}, 0.02 \%$ glucose, $0.2 \%$ sucrose and $2 \%$ agar) at $4^{\circ} \mathrm{C}$. The stored strains were transferred and cultured at $30^{\circ} \mathrm{C}(\mathrm{F}$. verticilliodes $)$ or $25^{\circ} \mathrm{C}$ (F. graminearum) on MPA medium (solid malt peptone agar medium: $1.5 \%$ malt extract, $0.5 \%$ peptone, $0.1 \%$ glucose and $1.8 \%$ agar) for 7 days prior to use in bioassays. 


\section{Plant extracts}

The aerial parts of the plants were dried at room temperature in the dark for a week. Then, they were ground to a coarse powder and stored in sealed flasks at $-20^{\circ} \mathrm{C}$ until use. Each ground material (10 g) was sequentially extracted $(2 \times 100 \mathrm{ml})$ with hexane, ethyl acetate and metanol. The powdered plant material was exposed $48 \mathrm{~h}$ to each organic solvent, subsequently trapped in a Whatman 4 filter paper and dried at $40^{\circ} \mathrm{C}$ till complete dryness before immersion in the next organic solvent. Each filtered organic fraction was evaporated under reduced pressure at $40^{\circ} \mathrm{C}$, the dry residues were weighed. The dry residues of the filtered organic fractions were stored at $-15{ }^{\circ} \mathrm{C}$ in sealed flasks until use.

\section{Broth microdilution tests}

They were performed in 96-well, flat-bottom microplates following the M38-A document from the National Committee for Clinical Laboratory Standards with some modifications (NCCLS, 2002). Fungal colonies were grown in Petri dishes for 7 to 15 days in solid MPA medium in the darkness at $30^{\circ} \mathrm{C}(F$. verticillioides $)$ or $25^{\circ} \mathrm{C}(F$. graminearum $)$. Then, the fungal colonies were washed with $2 \mathrm{~mL}$ of sterile distilled water to obtain suspensions of microconidia (F. verticillioides) or macroconidia (F. graminearum). The asexual spores were counted in a Neubauer chamber, and the suspension was diluted in semiliquid YES medium (yeast-malt extract-sucrose: $2 \%$ yeast extract, $15 \%$ sucrose, $0.05 \%$ magnesium sulphate, $0.125 \%$ agar) to obtain a density of $1 \times 10^{4}$ spores $\mathrm{mL}^{-}$

${ }^{1}$.The stock solutions of each organic extract were prepared in DMSO and diluted with culture medium to prepare two fold dilution series which were $2000,1000,500,250,125,63 \mu \mathrm{g} \mathrm{mL} \mathrm{L}^{-1}$, in semiliquid YES medium. The final volume in each well was $200 \mu \mathrm{L}$ containing $2 \%$ DMSO. This volume corresponded to $100 \mu \mathrm{L}$ of fungal spore suspension and $100 \mu \mathrm{L}$ of a dilution of an organic plant extract. Growth controls were prepared by adding in each well $100 \mu \mathrm{L}$ of YES medium plus $100 \mu \mathrm{L}$ of spore suspension. Controls of sterility were $200 \mu \mathrm{L}$ of YES medium per well. Each treatment (organic extracts or controls) included three wells per microplate. Each microplate was prepared twice. The microplates were incubated $72 \mathrm{~h}$ at $30^{\circ} \mathrm{C}(F$. verticillioides $)$ or $25^{\circ} \mathrm{C}(F$. graminearum). Then, the minimum concentration of each organic fraction required to inhibit $100 \%$ of the microbial growth (MIC) was visually determined. The MIC values presented in tables are means of three replicates obtained from two experiments.

\section{Isolation and identification of the antifungal constituents from the hexane extract of Euphorbia collina}

This article is protected by copyright. All rights reserved 
The hexane extract $(1.03 \mathrm{~g})$ was suspended in $20 \mathrm{ml}$ of hexane:ethyl acetate $(90: 10, \mathrm{v} / \mathrm{v})$ and loaded on an hexane-stabilized column which was packed with silica gel 60 (75 g, 230-400 mesh, Merck, Darmstadt, Germany). The column was eluted with a gradient of hexane-ethyl acetate (840 $\mathrm{mL}, 88: 12 ; 780 \mathrm{~mL}, 80: 20 ; 760 \mathrm{~mL}, 75: 25, \mathrm{v} / \mathrm{v})$, with collection of 119 fractions $(20 \mathrm{ml}$ each). Fractions were grouped in 20 pools (G1-G20) according to the TLC patterns observed after development with hexane-ethyl acetate 88:12 (v/v) and 3:1 (v/v). Then, the antifungal activity of the pools was tested in microdilution tests at concentrations of 1500, 750, 375, 188, 94, 47 and 23 $\mu \mathrm{g} / \mathrm{ml}$. Pool G10 was evaporated under reduced pressure at $60^{\circ} \mathrm{C}$, its dry residue was solubilized in dichloromethane and then injected in a gas chromatograph ThermoElectron Model trace GC ultra (Thermo Electron Corp, Madison, WI) equipped with a column DB-5 (phenyl methyl siloxane; 30 $\mathrm{m} \times 0.25 \mathrm{~mm}$ ID, $0.25 \mu \mathrm{m}$ film thickness as stationary phase) and coupled to a mass spectrometry detector ThermoElectron Model Polaris Q (Thermo Electron Corp, Madison, WI). Helium was used as mobile phase at a flow of $1 \mathrm{ml} / \mathrm{min}$; split ratio: 10:1; injection volume: $1 \mu \mathrm{l}$; temperature program: $100{ }^{\circ} \mathrm{C}(4 \mathrm{~min}), 100-280^{\circ} \mathrm{C}\left(\mathrm{ramp} 10^{\circ} \mathrm{C} / \mathrm{min}\right), 300^{\circ} \mathrm{C}(12 \mathrm{~min})$; mass analyser: ion trap; ionization type: electron impact at $70 \mathrm{eV}$; method of acquisition: full scan: 50-500 a.m.u.; ionization time: $0.25 \mathrm{~min}$. The constituents of pool G10 were identified by matching of their mass spectra fragmentation patterns with those stored in the Wiley/NIST database and data previously published (Zare et al., 2015). Retention index of each identified compound was calculated in relation to $n$-alkanes (Aristimuño Ficoseco et al., 2014).

The dry residue of G10 was dissolved in a small volume of $4 \%$ isopropanol in acetonitrile and filtered through a $0.22 \mu \mathrm{m}$ PTFE membrane. The filtrate was used in multiple injections performed in a HPLC coupled to an ultraviolet detector set at $210 \mathrm{~nm}$ (Masohan and Bhatia, 1996) and equipped with an IB-SIL 5 C18 column $(250 \times 10 \mathrm{~mm}, 5 \mu \mathrm{m})$ from Phenomenex. Injections were performed through a Rheodyne injector fitted with a $500-\mu 1$ loop. Flow was $2.8 \mathrm{~mL} / \mathrm{min}$. Fractions F1 and F2 corresponding to peaks were collected and dried under reduced pressure. A small aliquot of F1 and F2 was dissolved in dichloromethane and injected in GC-MS to check composition. F1, F2 and G10 were dissolved in DMSO and used for broth microdilution tests following the protocol previously described for the organic extracts.

\section{Joint action of the hexane extract of Euphorbia collina, F1 and F2 with commercial antifungals}

The hexane extract of E. collina, F1 and F2 were tested in combination with tebuconazole and potassium sorbate on strains of $F$. verticillioides and $F$. graminearum by the chessboard technique 
and the inhibitory fractionated concentration (FICI) was calculated as: FICI $=($ Concentration of A in $\mathrm{MIC}_{\mathrm{A}+\mathrm{B}} /$ Concentration of $\mathrm{A}$ in $\left.\mathrm{MIC}_{\mathrm{A}}\right)+\left(\right.$ Concentration of $\mathrm{B}$ in $\mathrm{MIC}_{\mathrm{A}+\mathrm{B}} /$ Concentration of $\mathrm{B}$ in $\mathrm{MIC}_{\mathrm{B}}$ ). Interpretation of FICI: $\leq 0.5$, synergy; 0.5-4.0, no interaction; > 4.0, antagonism (Vitale et al., 2005).

\section{Antimycotoxigenic effect of F1, F2 and their mixtures with potassium sorbate}

The antifumonisin effect of F1, F2 and mixtures of these compounds with potassium sorbate on toxin production by $F$. verticillioides and $F$. graminearum was then tested. Strains were cultivated in a medium depicted by López-Errasquín et al. (2007) containing $0.05 \%$ malt extract, $0.1 \%$ yeast extract, $0.1 \%$ peptone, $0.1 \% \mathrm{KH}_{2} \mathrm{PO}_{4}, 0.03 \% \mathrm{MgSO}_{4} 7 \mathrm{H}_{2} \mathrm{O}, 0.03 \% \mathrm{KCl}, 0.005 \% \mathrm{ZnSO}_{4} 7 \mathrm{H}_{2} \mathrm{O}$, $0.001 \% \mathrm{CuSO}_{4} 5 \mathrm{H}_{2} \mathrm{O}$ and $2 \%$ fructose. In the case of the $F$. graminearum strains, they were cultivated in $0.1 \%$ yeast extract, $0.1 \%$ peptone and $5 \%$ glucose (Ueno et al., 1975). F1, F2 and their mixtures with potassium sorbate were dissolved in $96 \%$ ethanol and added to $8 \mathrm{ml}$ of each medium previously poured in $125 \mathrm{ml}$ Erlenmmeyer flasks. Then, the media were inoculated with 1 $\mathrm{ml}$ of medium containing $10^{4}$ conidia of $F$. verticillioides or $F$. graminearum. Concentrations of F1 and F2 were tested at 94, 188 and $375 \mu \mathrm{g} / \mathrm{ml}$ while the mixtures of F1+potassium sorbate and F2+potassium sorbate were assayed at $12+23,23+47$ and $47+94 \mu \mathrm{g} / \mathrm{ml}$. The Erlenmeyers were

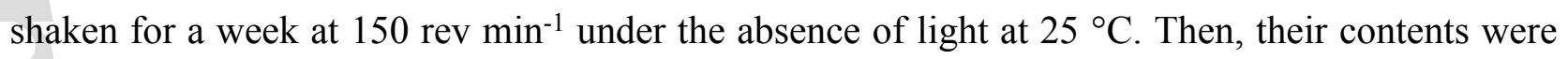
centrifuged at $3000 \mathrm{~g}$ for $10 \mathrm{~min}$. Mycotoxins were measured in the supernatants while the mycelial pellets were freeze dried during $48 \mathrm{~h}$ and weighed to establish the fungal biomass. Fumonisins and deoxynivalenol were measured with Elisa kits (Ridascreen Fast fumonisin and Fast DON, Biopharm, Germany) according to the manufacturer's instructions. They were expressed as $\mu \mathrm{g}$ mycotoxins/g of dry fungal biomass. The data recorded were subjected to ANOVA and differences among means were established by Dunnet T3 test. The statistical analyses were performed at $P=0.05$.

\section{ACNOWLEDGEMENTS}

This research was partially supported by a grant of the Agencia Nacional de Promoción Científica y Tecnológica of Argentina (PICT 2015 1572).

\section{CONFLICT OF INTEREST DISCLOSURE}

No conflict of interest declared 


\section{REFERENCES}

Abidi, S.L. (2001) Chromatographic analysis of plant sterols in foods and vegetable oils. $J$. Chromatogr. A 935, 173-201.

Alvarez, H.L., Marrón, Y., Mondino, M., Fernandez, E., Toso, F., Catalán, C.A.N. (2018) Actividad antihelmíntica in vitro de dos especies del género Euphorbia contra larvas infectantes de Ancylostoma caninum. Dominguezia 34, 75-76.

Aristimuño Ficoseco, M.E., Vattuone, M.A., Audenaert, K., Catalán, C.A.N., Sampietro, D.A. (2014) Antifungal and antimycotoxigenic metabolites in Anacardiaceae species from northwest Argentina: isolation, identification and potential for control of Fusarium species. J. Appl. Microbiol. 116, 1262-1273.

Barboza, G.E., Cantero, J.J., Núñez, C., Pacciaroni, A., Espinar, L.A. (2009) Medicinal plants: A general review and a phytochemical and ethnopharmacological screening of the native Argentine Flora. Kurtziana 34, 7-365.

Belizán, M.,Gomez, A., Terán Baptista, Z., Jiménez, C.,Catalán, C.,Sampietro, D.A. (2019) Influence of water activity and temperature on growth and production of trichothecenes by $F$. graminearum and related species in maize. Int. J. Food Microbiol. 305, 108242.

Bhakuni, D.S., Bittner, M., Marticorena, C., Silva, M., Weldt, E., Melo, E., Zemelman, R. (1974) Screening of Chilean Plants for Antimicrobial Activity. Lloydia 37, 12-17.

Bickii, J., Tchouyab, R.J.F., Tchouankeub, J.C., Tsamo, E. (2007) The antiplasmodial agents of stem bark of Entandrophragma Angolense(Meliaceae). Afr. J. Trad. CAM 4,135- 139.

De Pascual, T., Urones, J.G., Marcos, I.S., Basabe, Ma. P., Sexmero, C., Fernandez Moro, R. (1987). Triterpenes from Euphorbia broteri. Phytochemistry 26, 1767-1776.

Brauer, V., Rezende, C., Pessoni, A., Nayaka, S.,Gupta, V.,Almeida, F. (2019) Antifungal agents in agriculture:friends and foes of public health. Biomolecules $\mathbf{9}, 521$.

Castro, J.C., Pante, G.C., Centenaro, B.M., Ribeiro De Almeida, R.T., Pilau, E.J., Prado Dias Filho, B., Galerani Mossini, Sa., De Abreu Filho, B.A., Matioli, G., Machinski Junior, M. (2020) Antifungal and antimycotoxigenic effects of Zingiber officinale, Cinnamomum zeylanicum and Cymbopogon martinii essential oils against Fusarium verticillioides. Food Add. Contamin. Part A 1, 1-11.

EFSA (2015) Scientific opinion on the re-evaluation of sorbic acid (E 200), potassium sorbate (E202) and calcium sorbate (E203) as food additives. EFSA Journal 13, 4144.

This article is protected by copyright. All rights reserved 
Haraguchi, H., Kataoka, S., Okamoto, S., Hanafi, M., Shibata, K. (1999) Antimicrobial triterpenes from Ilex integra and the mechanism of antifungal action. Phytother. Res. 13, 151-156.

Jiménez, C.M., Sampietro, D.A., Sgariglia, M.A., Soberón, J.R., Vattuone, M.A. (2014) Isolation, identification and usefulness of antifungal compounds from Zuccagnia punctata for control of toxigenic ear rot pathogens. Nat. Prod. Commun. 9, 1461-1464.

Kamle, M., Mahato, D.K., Devi, S., Lee, K.E., Kang, S.G., Kumar, P. (2019) Fumonisins: impact on agriculture, food, and human health and their management strategies. Toxins 11, 328.

Khameneh, B., Iranshahy, M., Soheili, V., Sedigheh, B., Bazzaz, F. (2019) Review on plant antimicrobials: a mechanistic viewpoint.Antimicrob. Resist. Infect. Control 8, 118.

Lamberti, R.O., Troiani, H.O., Steibel, P., Toso, R.E., Boeris, M.A., Gino, L.M., Calvo, C., Bertorello Mascaró, G., Giraudo, L.M., Genero, G. (2009) Cribado antihelmíntico de plantas recolectadas en la provincia de La Pampa. Ciencia Veterinaria 11, 26-31.

López-Errasquín, E., Vázquez, C., Jiménez, M., González-Jaén, M.T. (2007) Real-time RT-PCR assay to quantify the expression of FUM1 and FUM19 genes from the fumonisin-producing Fusarium verticillioides. J. Microbiol. Methods 68, 312-317.

Masohan, A., Bhatia, V.K. (1996) HPLC in the analysis of steroidal compound mixtures as applied to biocrudes. J. Chrom. Sci. 34, 550-555.

Myburg, R., Dutton, M.,Chuturgoon, A. (2002) Cytotoxicity of FB1,diethylnitrosamine, and catechol on SNO esophageal cancer cell line. Environ. Health Perspect. 110, 813-815.

NCCLS. (2002) Performance standards for antimicrobial susceptibility testing. Twelfth Informational Supplement. NCCLS Document M100-S12. Wayne, PA, USA: NCCLS.

Vitale, R.G., Afeltra, J., Dannaoui, E. (2005) Antifungal combinations. Methods Mol. Med. 118, 143-152.

Payne, A.,Mukhopadhyay, A.,Deka, S.,Saikia, L.,Nandi, S. (2015) Anti-vibrio and antioxidant properties of two weeds: E. serpens and A. viridis.J. Med. Plant Res. 9, 170-178.

Pestka, J.J. (2008) Mechanisms of deoxynivalenol-induced gene expression and apoptosis. Food Addit. Contam. 24, 1-13.

Plumridge, A., Hesse, S.J., Watson, A.J., Lowe, K.C., Stratford, M., Archer, D.B. (2004) The weak acid preservative sorbic acid inhibits conidial germination and mycelial growth of Aspergillus niger through intracellular acidification. Appl. Environ. Microbiol. 70, 3506-3511.

Ragasa, C.Y., Jorvina, K., Rideout, J.A. (2004) Antimicrobial compounds from Artocarpus heterophyllus. Philipp. J. Sci. 133, 97-101. 
Sakuda, S., Yoshinari, T., Furukawa, T., Jermnak, U., Takagi, K., Iimura, K., Yamamoto, T., Suzuki, M., Nagasawa, H. (2016) Search for aflatoxin and trichothecene production inhibitors and analysis of their modes of action. Biosci. Biotech. Biochem. 80, 43-54.

Sampietro, D.A., Gómez, A.A., Jiménez, C.M., Lizarraga, E.F., Ibatayev, A.Z., Suleimen, Y.M., Catalán, C.A.N. (2016) Chemical composition and antifungal activity of essential oils from medicinal plants of Kazakhstan. Nat. Prod. Res. 31, 1464-1467.

Sofos, J.N., Busta, F.F. (1981) Antimicrobial activity of sorbate. J. Food Prot. 44, 614-622.

Ueno, Y., Sawano, M., Ishii, K. (1975) Production of trichothecene mycotoxins by Fusarium species in shake culture. J. Appl. Microbiol. 30, 4-9.

Zare, S.,Ghaedi, M., Mirin, R.,Heiling, S.,Asadollahi, M., Baldwin, I.,Jassbia, A. (2015) Phytochemical investigation on E. macrostegia. Iran J. Pharm. Res. 14,243-249.

Zhang, Z., Luo, Z., Shi, H., Zhang, L., Ma, X. (2017) Research advance of functional plant pharmaceutical cycloartenol about pharmacological and physiological activity. China J. Chin. Mat. Med. 3, 433-437.

\section{Figure captions}

Figure 1 Gas chromatography coupled to mass spectrometry of pool G10: (A) Chromatogram showing peaks at 14.708 and 15.339 min. Scanned mass spectra of these peaks are shown in (B) and $(\mathrm{C})$, respectively. 
Table 1. Values of inhibitory concentrations of $50 \%$ of fungal growth ( $\mathrm{IC}_{50}$ ) obtained for the ethyl acetate and hexane extracts of Euphorbia collina against strains of Fusarium vertillioides (NRRL 25457 and LABI7) and F. graminearum (NRRL 28063 and LABI11).

\begin{tabular}{|c|c|c|c|c|}
\hline & \multicolumn{4}{|c|}{$\mathrm{IC}_{50}(\mu \mathrm{g} / \mathrm{ml})^{1}$} \\
\hline & NRRL 25457 & LABI7 & NRRL 28063 & LABI11 \\
\hline Ethyl acetate extract & $1451(1380-1520)$ & $1325(1270-1495)$ & 1447 (1413-1495) & $1467(1407-1501)$ \\
\hline Hexane extract & $814(781-925)$ & $824(791-915)$ & $360(295-394)$ & $392(315-454)$ \\
\hline Tebuconazole & $0.06(0.04-0.07)$ & $0.06(0.04-0.07)$ & $0.04(0.02-0.05)$ & $0.03(0.01-0.04)$ \\
\hline Potassium sorbate & $1450(1350-1513)$ & $1490(1310-1550)$ & 1435 (1330-1490) & $1446(1390-1500)$ \\
\hline
\end{tabular}

${ }^{1} 95 \%$ confidence intervals are indicated between parentheses. 
Table 2. Values of minimum inhibitory concentration (MIC) obtained for pool G10 recovered from column chromatography of the hexanic extract of Euphorbia collina and fractions F1 and F2 separated from G10 after HPLC. The tests for antifungal activity were performed against strains of Fusarium vertillioides (NRRL 25457 and LABI7) and F. graminearum (NRRL 28063 and LABI11).

\begin{tabular}{|c|c|c|c|c|}
\hline & \multicolumn{4}{|c|}{$\mathrm{MIC}(\mu \mathrm{g} / \mathrm{ml})^{1}$} \\
\hline & NRRL 25457 & LABI7 & NRRL 28063 & LABI11 \\
\hline G10 & 1500 & 1500 & 750 & 750 \\
\hline $\mathrm{F} 1$ & 1500 & 1500 & 750 & 750 \\
\hline $\mathrm{F} 2$ & 1500 & 1500 & 750 & 750 \\
\hline $\begin{array}{l}\text { Potassium } \\
\text { sorbate }\end{array}$ & 3000 & 3000 & 3000 & 3000 \\
\hline Tebuconazole & 2 & 2 & 2 & 2 \\
\hline
\end{tabular}




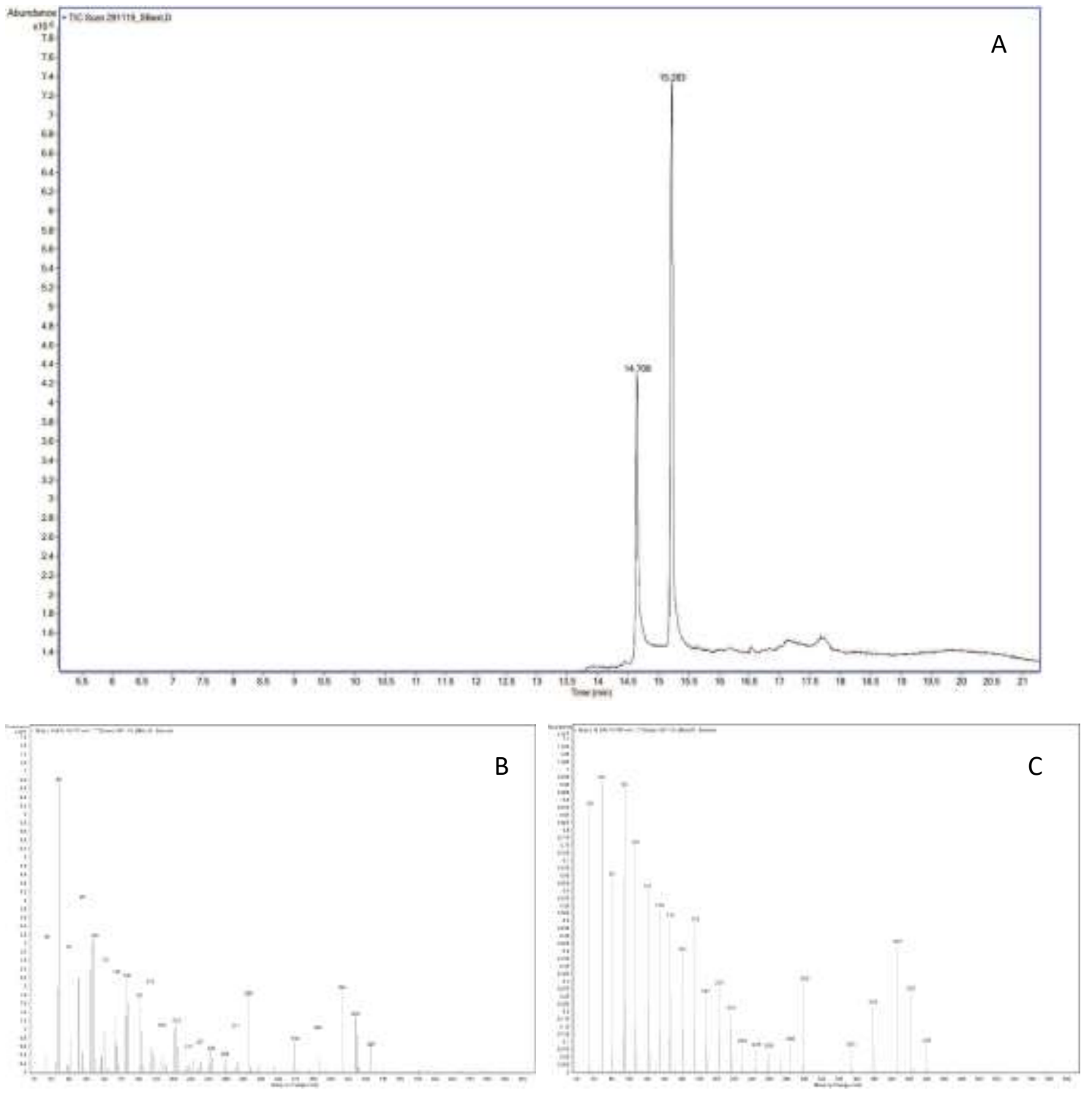

Figure 1 
Table 3. GC-MS analysis of pool G10

\begin{tabular}{|c|c|c|c|c|}
\hline $\begin{array}{l}\text { Arithmetic } \\
\text { Index }\end{array}$ & $\begin{array}{l}\text { Purity } \\
(\%)\end{array}$ & $\begin{array}{c}{\left[\mathrm{M}^{+}\right]} \\
\mathrm{m} / \mathrm{z}(\%)\end{array}$ & Major fragment ions, $\mathrm{m} / \mathrm{z}(\%)$ & Compound \\
\hline 2816 & 51 & $426(11)$ & $\begin{array}{l}55(46), 69(100), 81(42), 95 \\
(60), 109(46), 121(38), 135(35), \\
147(32), 161(25), 175(30), 187 \\
(15), 203(18), 215(9), 231(10), \\
243(9), 259(8), 271(15), 286 \\
(18), 297(5), 315(5), 339(29), \\
365(15), 393(29), 408(20)\end{array}$ & Cycloartenol \\
\hline 3108 & 49 & $440(10)$ & $\begin{array}{l}55(100), 69(100), 81(65), 95 \\
(93), 107(75), 121(69), 135(54), \\
147(50), 161(40), 175(48), 187 \\
(25), 203(28), 216(19), 229(9), \\
245(8), 259(7), 285(9), 300 \\
(29), 353(8), 379(23), 407(43), \\
422(28)\end{array}$ & $\begin{array}{c}\text { 24-methylene } \\
\text { cycloartanol }\end{array}$ \\
\hline
\end{tabular}


Table 4. Joint action of commercial antifungals with F1 (98\% cycloartenol) and F2 (97\% 24-methylenecycloartenol) determined by the checkerboard technique against Fusarium verticillioides (NRRL 25457 and LABI7) and F. graminearum (NRRL 28063 and LABI11).

\begin{tabular}{|c|c|c|c|c|c|c|}
\hline & \multicolumn{2}{|l|}{ FICI } & \multirow[t]{2}{*}{ Joint effect $^{1}$} & \multicolumn{2}{|l|}{ FICI } & \multirow[t]{2}{*}{ Joint effect $^{1}$} \\
\hline & NRRL 25457 & LABI7 & & NRRL 28063 & LABI11 & \\
\hline \multicolumn{7}{|c|}{ Sorbate potassium } \\
\hline$+\mathrm{F} 1$ & 0.31 & 0.31 & synergism & 0.16 & 0.16 & synergism \\
\hline$+\mathrm{F} 2$ & 0.13 & 0.13 & synergism & 0.13 & 0.13 & synergism \\
\hline \multicolumn{7}{|c|}{ Tebuconazole } \\
\hline$+\mathrm{F} 1$ & 1.00 & 1.00 & additivism & 1.00 & 1.00 & additivism \\
\hline$+\mathrm{F} 2$ & 0.75 & 0.75 & additivism & 0.75 & 0.75 & additivism \\
\hline
\end{tabular}


Table 5. Impact of sublethal concentrations of F1 (98\% cycloartenol), F2 (97\% 24methylenecycloartenol) and their mixtures with potassium sorbate (PS) on production of deoxynivalenol (DON) and fumonisins (Fum) recorded for strains of $F$. verticillioides and $F$. graminearum. Potassium sorbate was included as control.

\begin{tabular}{|c|c|c|c|c|c|c|c|c|}
\hline \multirow[b]{3}{*}{$\begin{array}{l}\text { Concentration } \\
\qquad(\mu \mathrm{g} / \mathrm{ml})\end{array}$} & \multicolumn{4}{|c|}{ Strains of $F$. graminearum } & \multicolumn{4}{|c|}{ Strains of $F$. verticillioides } \\
\hline & \multicolumn{2}{|c|}{ NRRL 28063} & \multicolumn{2}{|c|}{ LABI11 } & \multicolumn{2}{|c|}{ NRRL 25457} & \multicolumn{2}{|c|}{ LABI7 } \\
\hline & $\begin{array}{c}\text { DON } \\
(\mu \mathrm{g} / \mathrm{mg})^{1}\end{array}$ & $\begin{array}{l}\text { Biomass } \\
\text { (ref. control) }\end{array}$ & $\begin{array}{c}\text { DON } \\
(\mu \mathrm{g} / \mathrm{mg})^{1}\end{array}$ & $\begin{array}{l}\text { Biomass } \\
(\text { ref control })^{2}\end{array}$ & $\begin{array}{c}\text { Fum } \\
(\mu \mathrm{g} / \mathrm{mg})^{1}\end{array}$ & $\begin{array}{l}\text { Biomass } \\
\text { (ref. } \\
\text { control) }{ }^{2}\end{array}$ & $\begin{array}{c}\text { Fum } \\
(\mu \mathrm{g} / \mathrm{mg})^{1}\end{array}$ & $\begin{array}{c}\text { Biomass } \\
(\text { ref. control })^{2}\end{array}$ \\
\hline Control & $0.79 \pm 0.01 \mathrm{a}$ & $1.00 \pm 0.01$ & $0.85 \pm 0.02 \mathrm{a}$ & $1.00 \pm 0.01$ & $3.91 \pm 0.01 \mathrm{a}$ & $1.00 \pm 0.02$ & $4.10 \pm 0.02 \mathrm{a}$ & $1.00 \pm 0.01$ \\
\hline \multicolumn{9}{|l|}{ F1 } \\
\hline 94 & $0.15 \pm 0.01 \mathrm{c}$ & $0.98 \pm 0.01$ & $0.16 \pm 0.02 b$ & $0.95 \pm 0.01$ & $4.10 \pm 0.02 \mathrm{a}$ & $1.05 \pm 0.02$ & $3.90 \pm 0.02 \mathrm{a}$ & $1.00 \pm 0.01$ \\
\hline 188 & ND & $1.08 \pm 0.01$ & ND & $0.50 \pm 0.01$ & $2.58 \pm 0.02 b$ & $1.00 \pm 0.01$ & $2.87 \pm 0.01 b$ & $1.00 \pm 0.01$ \\
\hline 375 & ND & $0.87 \pm 0.03$ & ND & $0.89 \pm 0.03$ & ND & $0.80 \pm 0.02$ & ND & $0.90 \pm 0.03$ \\
\hline \multicolumn{9}{|l|}{$\mathrm{F} 2$} \\
\hline 94 & $0.20 \pm 0.01 \mathrm{c}$ & $1.11 \pm 0.01$ & $0.11 \pm 0.01 \mathrm{~b}$ & $0.98 \pm 0.01$ & $3.89 \pm 0.04 \mathrm{a}$ & $1.16 \pm 0.01$ & $3.95 \pm 0.02 \mathrm{a}$ & $1.15 \pm 0.02$ \\
\hline 188 & ND & $1.00 \pm 0.01$ & ND & $1.00 \pm 0.01$ & $2.89 \pm 0.04 \mathrm{c}$ & $1.00 \pm 0.02$ & ND & $1.00 \pm 0.03$ \\
\hline 375 & ND & $0.95 \pm 0.02$ & ND & $0.95 \pm 0.02$ & ND & $0.85 \pm 0.01$ & ND & $0.80 \pm 0.01$ \\
\hline \multicolumn{9}{|l|}{$\mathrm{F} 1+\mathrm{PS}(2: 1)$} \\
\hline $47+23$ & $0.45 \pm 0.01 b$ & $1.00 \pm 0.01$ & $0.31 \pm 0.01 \mathrm{c}$ & $1.00 \pm 0.01$ & $2.50 \pm 0.02 \mathrm{~d}$ & $1.00 \pm 0.01$ & $2.70 \pm 0.02 b$ & $1.00 \pm 0.01$ \\
\hline $94+47$ & $0.41 \pm 0.02 b$ & $0.68 \pm 0.01$ & $0.28 \pm 0.02 c$ & $0.75 \pm 0.01$ & $1.50 \pm 0.02 \mathrm{~d}$ & $1.00 \pm 0.03$ & $1.89 \pm 0.02 \mathrm{c}$ & $1.00 \pm 0.01$ \\
\hline $188+94$ & - & NG & - & NG & $0.76 \pm 0.02 \mathrm{e}$ & $0.85 \pm 0.02$ & $1.00 \pm 0.02 \mathrm{f}$ & $0.79 \pm 0.03$ \\
\hline \multicolumn{9}{|l|}{$\mathrm{F} 2+\mathrm{PS}(1: 2)$} \\
\hline $12+23$ & $0.32 \pm 0.02 \mathrm{~d}$ & $1.00 \pm 0.01$ & $0.29 \pm 0.01 \mathrm{c}$ & $1.05 \pm 0.01$ & $2.70 \pm 0.01 \mathrm{c}$ & $1.00 \pm 0.01$ & $1.90 \pm 0.01 \mathrm{c}$ & $1.08 \pm 0.01$ \\
\hline $23+47$ & $0.21 \pm 0.02 \mathrm{c}$ & $0.40 \pm 0.02$ & $0.21 \pm 0.01 b$ & $0.45 \pm 0.02$ & $1.45 \pm 0.01 \mathrm{~d}$ & $1.00 \pm 0.01$ & $1.11 \pm 0.01 \mathrm{~d}$ & $1.00 \pm 0.01$ \\
\hline $47+94$ & $0.16 \pm 0.01 \mathrm{c}$ & $0.30 \pm 0.01$ & $0.13 \pm 0.01 b$ & $0.28 \pm 0.01$ & $0.56 \pm 0.01 \mathrm{e}$ & $0.90 \pm 0.02$ & $0.85 \pm 0.02 \mathrm{e}$ & $0.95 \pm 0.02$ \\
\hline \multicolumn{9}{|l|}{ PS $(\mu \mathrm{g} / \mathrm{ml})$} \\
\hline 94 & $0.94 \pm 0.02 \mathrm{a}$ & $1.10 \pm 0.01$ & $0.86 \pm 0.01 \mathrm{a}$ & $1.15 \pm 0.01$ & $4.05 \pm 0.01 \mathrm{a}$ & $1.20 \pm 0.01$ & $4.21 \pm 0.01 \mathrm{a}$ & $1.10 \pm 0.01$ \\
\hline 188 & $1.35 \pm 0.02 \mathrm{c}$ & $1.00 \pm 0.02$ & $0.99 \pm 0.01 \mathrm{a}$ & $1.00 \pm 0.02$ & $4.00 \pm 0.01 \mathrm{a}$ & $1.08 \pm 0.02$ & $4.10 \pm 0.01 \mathrm{a}$ & $1.15 \pm 0.02$ \\
\hline 375 & $1.45 \pm 0.02 \mathrm{c}$ & $1.08 \pm 0.01$ & $1.25 \pm 0.01 \mathrm{c}$ & $1.20 \pm 0.01$ & $4.40 \pm 0.01 \mathrm{a}$ & $1.10 \pm 0.01$ & $5.00 \pm 0.01 \mathrm{~d}$ & $1.10 \pm 0.01$ \\
\hline
\end{tabular}

${ }_{1}^{1} \mu \mathrm{g}$ of mycotoxin per mg of dry fungal biomass $60 \mathrm{mg}$ of dry weight/Petri dish. ND: Not detected. NG: No growth Means in the same column with the same letter are not significantly different (Dunnet T3 test, $\mathrm{p}=0.05$ ).

Data are reported as mean values \pm standard deviation, based on two experiments where each treatment had three replications. 